\title{
A Case of Granular Cell Tumor of Postauricular Area
}

\author{
Hyun-Min Lee, Eui-Kyung Goh, Sung-Hwan Park and Soo-Keun Kong \\ Department of Otorhinolaryngology-Head and Neck Surgery, Pusan National University School of Medicine, Busan, Korea
}

\section{이개후부에 발생한 과립세포종 1 예}

이현민 · 고의경 · 박성환 · 공수근

부산대학교 의학전문대학원 이비인후과학교실

\author{
Received June 29, 2009 \\ Revised September 17, 2009 \\ Accepted September 24, 2009 \\ Address for correspondence \\ Soo-Keun Kong, MD \\ Department of Otorhinolaryngology- \\ Head and Neck Surgery, \\ Pusan National University School of \\ Medicine, 305 Gudeok-ro, Seo-gu, \\ Busan 602-739, Korea \\ Tel $+82-51-240-7335$ \\ Fax $+82-51-246-8668$ \\ E-mail kongsk@pusan.ac.kr
}

Granular cell tumor (GCT) is a relatively rare tumor. GCT can originate from any site of human body, including subcutaneous tissue, skin, breast, digestive system and respiratory system. It occurs mostly in the head and neck region, especially in the oral cavity and tongue. Histopathologically, GCT consists of polymorphic and polygonal cells. The cytoplasm of cells has abundant eosinophilic granules. In immunohistochemical studies, these eosinophilic granules appear positive for S-100 protein. Surgical excision is the first choice of treatment of GCT; recurrence is rare when proper excision is done with a sufficient margin. We have experienced a case of GCT that originated from the postauricular area, and report this case with a review of literatures.

Korean J Otorhinolaryngol-Head Neck Surg 2009;52:921-3

Key Words Granular cell tumor · Auricle.
서 론

과립세포종은 비교적 드문 양성 종양으로, 아직까지 종양 의 기원과 성격이 정확하게 알려지지 않았으며, 피부, 혀, 유 방, 후두, 상부소화기관, 호흡기 등 전신에 발생할 수 있다. 구 강의 설부에 가장 잘 발생하고, 국내에서는 후두에 발생한 증 례 수 예가 보고되었다. ${ }^{1-3)}$ 저자들은 이개후부에 발생한 과립 세포종 1 예를 경험하였기에 문헌고찰과 함께 보고하고자 한다.

\section{증 례}

47세의 여자 환자가 4 개월 전부터 촉지된 우측 이개후 부의 종물을 주소로 내원하였다. 환자는 특이한 과거력, 가 족력 및 사회력을 가지지 않았다. 환자의 이개후부 종물은 처음에는 작고, 통증과 압통은 없었으나 크기증가 소견이 있어 타 병원에서 절개생검을 시행하였고 병리 소견상 육아 종성 결절로 진단되었다. 절개생검 이후에도 종물의 크기증 가로 본원에 내원하였다. 내원 당시 $3.5 \times 1.5 \mathrm{~cm}$ 의 단단한 비가동성 종물이 우측 이개후부에서 관찰되었으며(Fig. 1),
이개후부종물의 절제술을 시행하기로 하였다. 술 전 영상검 사로 측두골 컴퓨터단층촬영을 시행하였고 이개후부 및 이 하선천엽 상부에까지 이르는 종물을 확인하였다.

전신마취하에 우측 이개후부종물 절제술을 시행하였으며, 수술 소견상 종물은 매우 단단하였고 이하선천엽과 이개연 골에 심하게 유착되어 있는 소견을 관찰할 수 있었다. 종물 과 유착된 연골의 일부를 함께 제거하였고, 이하선천엽의 일 부를 같이 제거하여 종양 절제연을 확보하였다. 병리조직검 사 소견상 경계가 불분명하고 주변으로 침윤하는 성질의 종 양세포들이 보였으며, 각각의 종양세포는 핵은 작지만 과립 이 많은 세포질이 풍부한 소견을 관찰할 수 있었다(Fig. 2A) 면역조직화학검사상 $\mathrm{CD} 68$ 에는 음성을 보였으나 S-100 단백에는 강한 양성반응을 나타내어 과립세포종으로 진단 되었다(Fig. 2B). 현재 술 후 2 년째 재발 소견 없이 추적관 찰 중이다.

\section{고 찰}

과립세포종은 아직까지 정확한 조직학적 기원이 알려지지 
않은 양성종양으로 연령분포는 11 개월에서 85 세까지 다양 하게 분포되어 있으며) 주로 10 대에서 50대 사이에 많이 발생하는 것으로 알려져 있다. ${ }^{1,4)}$ 인종은 백인보다는 흑인이 더 많은 것으로 조사되었다. ${ }^{4)}$ 성별분포는 여러 연구에서 1.8 에서 $2.4: 1$ 의 비율로 여성이 남성보다 더 많다고 하였다. 5,6$)$ 과립세포종의 기원은 아직 정확하게 밝혀지지 않았다. 1926 년에 Abrikossoff가 이 종양을 처음으로 보고하였으며 당시 에는 근육에서 기원하는 종양으로 주장하였다. ${ }^{7)}$ 이후 1949 년에 Fust 등은 신경성 유래라고 하여 "granular cell neurofibroma”로 명명하였으며," 1962 년에 Fisher와 Wechsler" 는 현미경적, 조직화학적 연구상 schwann cell 기원으로 생 각된다 하여 "granular cell schwannoma"로 명명하였다. 이 외에도 여러 저자들이 새로운 가설을 제시해왔으나 현재는 1971년 WHO에서 과립세포종(granular cell tumor, GCT) 으로 제안한 이래 이 명칭으로 불리고 있다. 최근 연구들에 서는 신경기원설이 일반적으로 받아들여지고 있는데, 이 가 설은 전자 현미경 소견상 신경세사(neurofilament) 및 신

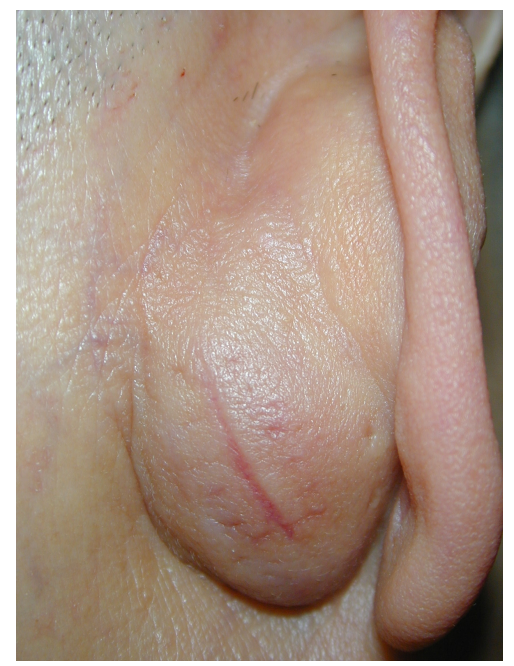

Fig. 1. Preoperative local finding shows hard fixed mass on right retroauricular area. There's a $1.5 \mathrm{~cm}$ sized scar of excisional biopsy on retroauricular mass which was performed 6 weeks ago. 경세관(neurotubule)이 세포 내에서 관찰되며, 신경조직과 관련된 항원인 S-100 단백이나 NSE (neuron specific enolase)에 면역조직화학 검사상 양성반응을 보이는 점 등에 의 하여 뒷받침된다. ${ }^{3,10)}$

발생 부위는 피하조직, 유방, 피부, 소화기, 호흡기, 생식 기, 신경계 등 신체의 거의 모든 부위에서 발생 가능한 것으 로 보고되고 있다. 그 중에서도 두경부에 발생하는 비율이 45 65\%로 가장 높았고 두경부 중에서 혀, 구강 내 점막, 경구개 등에 발생하는 비율이 $70 \%$ 정도였다. ${ }^{7)}$ 다른 부위 에는 피하조직에 $30 \%$, 유방에 $15 \%$, 호흡기에 $10 \%$ 등의 비율로 발생하는 것으로 보고되었다. ${ }^{7)}$ 본 증례에서는 과립 세포종이 드물게 보고된 부위인 이개후부에 발생하였으며, 지금까지 보고된 증례 일부에서 유사한 부위에서의 발생이 보고되었다. ${ }^{11,12)}$

증상은 일반적으로 종물 이외에는 특별히 발생하지 않지만 발생 부위에 따라서는 통증, 이물감, 호흡곤란 등 국소적인 증상이 발생할 수 있다.

진단은 조직생검에 의하여 가능하며 보통 종괴는 궤양을 형성하지 않는 결절의 형태로 나타나며 크기는 주로 2 5 cm 정도로 다양하다. ${ }^{7)}$ 현미경하에서 종양세포는 다형성이며 다 각형 또는 원형으로 세포 안에는 하나 또는 2 개의 중앙에 위 치한 핵이 관찰되고 세포질에는 호산성 과립이 풍부하게 함 유되어 있다. ${ }^{10)}$ 연구에 의하면 이러한 호산성 과립은 periodic acid schiff(PAS) 및 Sudan black B 염색으로 양성 을 보이고, 말초신경섬유에서처럼 S-100 단백에서 양성을 보인다. ${ }^{10)}$

과립세포종의 치료는 일반적으로 광범위 국소적 절제술로 완치를 기대할 수 있는 것으로 알려져 있고, ${ }^{1,6)}$ 절제 변연에 종양이 남아 있는 경우 재발이 흔하다고 알려져 있어 변연부 위에 남은 종양조직이 없는지 잘 확인해야 한다. ${ }^{7)}$ 국소적 절 제술 이외에도 발생 부위에 따라 다양한 치료방법이 시도되 고 있는데, 후두나 구강 내 병변을 $\mathrm{CO}_{2}$ laser로 제거하는 방 법이나, ${ }^{1-3)}$ 피부에 발생한 병변을 Mohs 수술을 통하여 제거

Fig. 2. Each tumor cells have granular eosinophilic cytoplasm and central nuclei with vesicular chromatin. Tumor cells are arranged in nest, which are surrounded by a desmoplastic stroma $(H \& E, \times 400)(A)$. Tumor cells are positive with immunohistochemical stain for $\mathrm{S}-100$ protein (S-100 protein, $\times 400)(B)$.
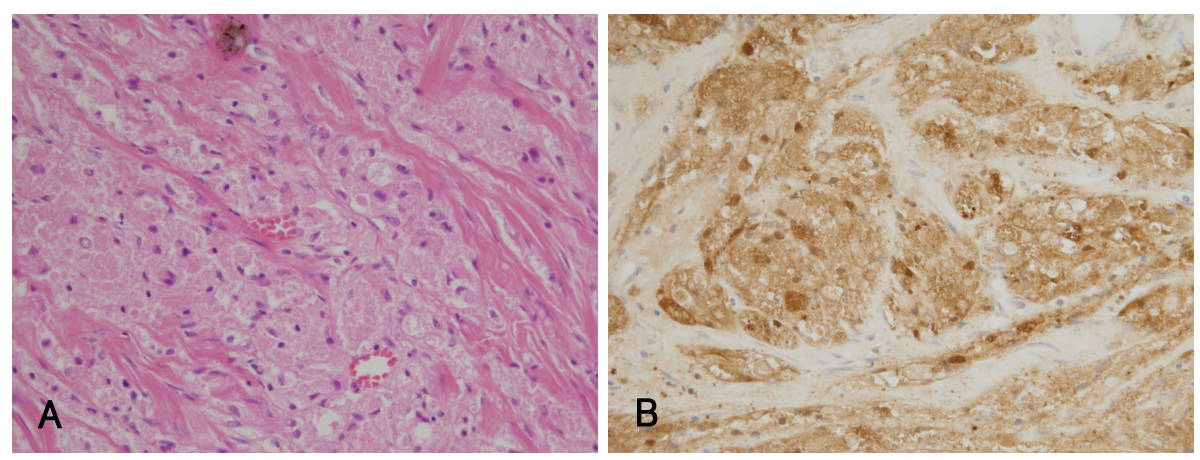
하는 방법 등이 소개되고 있다. ${ }^{13)}$

전체 과립세포종에서 1 3\%는 악성으로 전환될 수 있는 데, ${ }^{14)}$ 악성종양은 세포의 다형질과 과염색질화, 고배율상 10 개당 2 개 이상의 핵분열상, 괴사, 출혈, 전이 등의 특징과 함께 종양의 급속한 성장, 종양의 크기, 주위조직으로의 침 윤 등의 양상에 의해서 양성종양과 감별할 수 있다. ${ }^{1,7)}$ 악 성과립세포종은 병소의 국소제거와 함께 병변 주변부의 림 프절 또한 같이 제거해야 하며, ${ }^{6,15)}$ 병변과 림프절의 제거 이 후에도 재발과 전이 여부를 주의하여 경과관찰해야 한다. ${ }^{6)}$

이외에도 항암 치료나 방사선 치료를 시행해 볼 수 있다고 알려져 있는데 아직 정확한 효과는 알려져 있지 않다.7)

\section{Acknowledgments}

This work was supported by clinical research grant from Pusan National University Hospital (2008).

\section{REFERENCES}

1) Yoo YS. A case of granular cell tumor in the larynx. Korean J Otolaryngol-Head Neck Surg 1994;37 (4):833-8.

2) Choi HS, Lim JY, Yoo JB, Kim JH, Shin EA. A case of granular cell tumor of the vocal fold. Korean J Otolaryngol-Head Neck Surg 2002; 45 (12):1196-8.

3) Cho SH, Park KS, Woo JS, Jung KY. A case of granular cell tumor of the larynx. Korean J Otolaryngol-Head Neck Surg 2002;45 (11) :1114-7.

4) Chaudhry AP, Jacobs MS, SunderRaj M, Yamane GM, Jain R, Scharl- ock SE. A clinico-pathological study of 50 adult oral granular cell tumors. J Oral Med 1984;39(2):97-103, 118.

5) Miller A, Leiffer C, Chen SY, Harwick RD. Oral granular cell tumors Report of twenty-five cases with electron microscopy. Oral Surg Oral Med Oral Pathol 1977;44 (2):227-37.

6) Curtis BV, Calcaterra TC, Coulson WF. Multiple granular cell tumor: a case report and review of the literature. Head Neck 1997;19 (7):634-7.

7) Becelli R, Perugini M, Gasparini G, Cassoni A, Fabiani F. Abrikossoff's tumor. J Craniofac Surg 2001;12 (1):78-81.

8) Fust JA, Custer RP. On neurogenesis of so called granular cell myoblastoma. Am J Clin Pathol 1949;19:522-55.

9) Fisher ER, Wechsler H. Granular cell myoblastoma: a misnomer. Electron microscopic and histochemical evidence concering its schwann cell derivation and nature (granular cell schwannoma). Cancer 1962; 15:936-54.

10) Nakazato Y, Ishizeki J, Takahashi K, Yamaguchi H. Immunohistochemical localization of S-100 protein in granular cell myoblastoma. Cancer $1982 ; 49(8): 1624-8$.

11) Alidina $R$, Werschler $P$, Nigra $T$, Feldman $B$, Olding $M$, Williams CM. A solitary tumor on the earlobe. Granular cell tumor. Arch Dermatol $1994 ; 130(7): 913,916$.

12) Noonan JD, Horton CE, Old WL, Strokes TL. Granular cell myoblastoma of the head and neck: review of the literature and 10 year experience. Am J Surg 1979;138 (4) :611-4.

13) Chilukuri S, Peterson SR, Goldberg LH. Granular cell tumor of the heel treated with Mohs technique. Dermatol Surg 2004;30 (7):1046-9.

14) Felsenfeld RB, Mintz SM. Seventeen granular cell lip tumors in a sixyear-old boy. J Oral Maxillofac Surg 1988;46(7):614-7.

15) Khansur T, Balducci L, Tavassoli M. Granular cell tumor. Clinical spectrum of the benign and malignant entity. Cancer 1987;60 (2):220-2. 